\title{
TEKNOLOGI PLESTOSEN: SUATU HASIL ADAPTASI BIO-KULTURAL
}

\author{
Oleh: Harry Widianto
}

Faktor alam, manusia dan kebudayaan merupakan 3 faktor utama yang saling berinteraksi. Manusia merupakan faktor subyek, menghadapi alam untuk dapat melanjutkan kehidupannya. Suatu kehidupan yang panjang telah dilaluinya, dengan disertai tantangan hebat melalui seleksi alam: mereka yang sanggup mengatasi keganasan alam akan dapat melanjutkan kehidupannya, sedangkan yang tidak sanggup akan kandas. Seleksi alam dianggap sebagai suatu mekanisme pokok yang mengarahkan perubahan, dan adaptasi manusia terhadap lingkungan merupakan faktor penting untuk dapat bertahan.

Phenotipus manusia itu sendiri adalah hasil interaksi antara genetika dan lingkungannya. Genetika adalah gena-gena yang membentuk genotipus dan menentukan ciri-ciri, kemampuan dan arah perkembangan (Jacob, 1978: 4). Yang terlihat pada manusia atau sisa-sisa manusia adalah phenotipusnya, hasil interaksi antara genetipus dan lingkungannya. Phenotipus inilah yang tertinggal sebagai fosil, sedangkan genotipusnya sama sekali tidak diketahui.

Selain dipengaruhi oleh lingkungan, manusia juga mengubah lingkungannya, baik secara fisis maupun kimiawi. Adaptasi biokultural dilakukan. Dari proses tadi dihasilkan dua hal penting yaitu artefak dan ipsefak. Artefak adalah alat yang dibuat manusia untuk mengeksploitasi lingkungannya, dan ipsefak adalah satuan lingkungan yang diubah manusia dalam adaptasinya, misalnya hutan yang ditebas, lubang yang digali, pemukiman dan sebagainya (Jacob, 1978: 5). Artefak dipandang sebagai benda teknomik. Gambaran peri-laku manusia dapat dilihat melalui artefak dan ipsefaknya.

Dari Kala Plestosen di Indonesia, alat-alat batu merupakan ciri temuan yang menonjol. Kecenderungan pemilihan batu untuk membuat alat, terutama adalah batu kerakal, sangat erat hubungannya dengan ekologi pada saat itu. Batu adalah bahan alam yang mudah diperoleh manusia dan paling besar daya tahannya terhadap lingkungan hidup yang masih liar. Yang dipilih terutama dari jenis batuan volkanik kersikan dan batuan gamping kersikan, tetapi tidak sukar dibentuk melalui pemangkasan (Soejono, 1980: 38). Umumnya mempunyai kekerasan di atas 7 pada skala Mohs. Tempat pencariannya adalah sungai-sungai dan pegunungan di sekitar lingkungan hidup. Kemudian dibentuk ke dalam tradisi batu inti dan serpih. Dilihat dari bentuknya, fungsi atau kegunaan alat dapat diketahui. Alat batu inti yang berupa kapak penetak dan perimbas diduga untuk memotong tulang, sedangkan alat-alat serpih dan bilah untuk menya yat maupun menusuk daging. Dengan demikian dapat pula diketahui corak penghidupan jaman paleolitik, yaitu erat sekali dengan cara perburu 
an binatang dan pengumpul makanan dalam suatu tingkatan yang masih sederhana.

Terciptanya suatu alat tidak dapat dilepaskan dari manusia sebagai pendukungnya. Evolusi teknologi akan selalu mengikuti proses biologi yang terjadi. Evolusi biologis dan kultural akan selalu tetap berdampingan. Dari tingkat primitip, melalui perubahan-perubahan yang lambat, berkembang ke tingkat progresip. Proses evolusi kultural dari jaman paleolitik telah berhasil dirumuskan oleh Oakley (Oakley, 1972: 40-58). Kronologi yang dibuat oleh Oakley adalah sebagai berikut:

Kebudayaan batu kerakal (pebble tool), Kebudayaan kapak genggam (hand axe), Kebudayaan kapak perimbas (chopper tool), Kebudayaan serpih (flake tool) dan Kebudayaan bilah (blade tool). Setiap tahapan tersebut mencerminkan tahapan ketrampilan penciptanya. Evolusi bekerja pada populasi, pada !nggun genanya.

\section{II}

Evolusi adalah perubahan-perubahan berangsur dari masa ke masa, dari angkatan ke angkatan. Evolusi biologis merupakan perubahan frekuen si gena yang terjadi dari generasi ke generasi (Jacob, 1977: 35). Gena meru pakan satuan pewaris yang terkecil, yang terdapat berderet pada kromosom. Faktor pewaris dan lingkungan akan menimbulkan ciri-ciri pada makhluk hidup, termasuk manusia.

Dalam evolusi manusia Kala Plestosen terlihat beberapa proses penting yang terjadi. Pertama adalah sikap tubuh dan cara bergerak. Setiap gerak merupakan hal penting karena mempunyai rentetan akibat dalam evolusi manusia selanjutnya. Rentetan akibat tadi menimbulkan pengaruh terhadap struktur anatomi suatu individu, sehingga otomatis akan mempengaruhi pula gerakan-gerakan yang dilakukan. Dimulai dengan duduk tegak, berdiri tegak dan berjalan tegak. Dengan dilakukannya berjalan dan berlari tegak, maka suatu babakan baru dalam evolusi telah dicapai: penggunaan perkakas. Penyebab penting dalam penggunaan perkakas adalah bebasnya tangan oleh sikap tegak yang terjadi. Segala kegiatan yang dilakukan sepanjang hari,menggali akar dengan kayu, membalik batu mencari larva dan kumbang, menyambar dan memukul kodok dengan cepat, memecah biji-bijian dengan batu, semuanya cenderung meningkatkan dan mengembangkan ketangkasan tangan yang mereka miliki.

Kemampuan yang amat vital ini tergantung pada tulang pinggul, punggung, tungkai dan kaki (Howell, 1977: 56). Makhluk dengan tungkai panjang dan yang paling sering bersikap tegak dapat melihat binatang buas dengan cara terbaik dan dapat berlari dengan cepat. Cara gerak dengan cepat adalah dengan menggunakan kedua kaki. Keberhasilan melempar batu dan tongkat kayu secara kebetulan, mungkin membawa awal kesadaran akan kegunaan batu dan kayu sebagai senjata. Makhluk inilah yang mampu mempertahankan kelangsungan hidupriya.

Selain sikap tegak, yang penting dalám evolusi manusia adalah evolusi kepala. Evolusi kepala berhubungan erat sekali dengan alat pengunyah 
dan perkembangan otak. Bagi makhluk yang sering menggunakan alat, perkembangan otak menjadi sangat penting. Perubahan bentuk dan ukuran tengkorak dapat dianggap merupakan akibat dari tekanan seleksi untuk menambah ruangan otak. Tiga faktor berkaitan secara erat, yaitu bipedal (berjalan dengan kedua kaki), perkembangan otak dan penggunaan alat. Bipedal akan membebaskan tangan. Perkembangan otak akan meningkatkan kecerdasan, selanjutnya menimbulkan ide pembuatan alat. Perkembangan otak dan bipedal menimbulkan penciptaan dan penggunaan perkakas.

\section{III}

Perbedaan antara manusia dan binatang, terutama sekali terletak pada akal. Akal disebabkan oleh perkembangan otak. Akal inilah yang menyebabkan manusia terletak paling atas di alam. Hewan mengeksploitasi dan beradaptasi terhadap lingkungan dengan biologisnya, sedangkan manusia terutama melakukannya dengan hasil-hasilnya budayanya, jadi dengan cara-cara ekstra biologis atau supra-organisnya (Jacob, 1977: 35).

Artefak sebagai suatu hasil budaya manusia mempunyai sifat tersendiri, mulai dari tahap pengambilan bahan mentah, pengolahan, sampai pada tahap pembuangan. Setiap artefak mungkin dapat memberikan data tentang setiap tahap kegiatan manusia dan proses-proses antara unsur kehidupan masa lalu dapat ditemukan kembali. Dari Kala Plestosen di Indonesia, yang paling menonjol terlihat adalah pada segi teknologinya.

Segi sosial masih samar-samar, sedangkan segi Religius sama sekali belum terlihat. Teknologi Plestosen yang tertua berasal dari Kala Plestosen Tengah, yaitu ditonjolkan oleh teknologi kapak batu. Pembuatan alat-alat tersebut masih menunjukkan fungsi praktisnya saja, yang disesuaikan dengan keingirian dan tujuan penggunaannya. Berdasarkan pada bentuk dan teknologi yang diterapkan pada alat Plestosen, maka dapat diketahui bahwa corak kehidupan saat itu adalah berburu dan mengumpul makanan tingkat sederhana. Mereka hidup pada suatu ekologi yang masih liar, dengan cara berpindah-pindah. Pengamatan dalam segi teknologi dari artefak telah melahirkan gagasan-gagasan tentang tingkat kebudayaan manusia di masa lampau.

Keganasan alam telah mendorong penciptaan alat agar dapat bertahan, dan kawasan penyesuaian merupakan tantangan yang harus dihadapi. Mampu tidaknya suatu makhluk dalam mencipta alat banyak tergantung dari proses evolusi biologis yang dialaminya, terutama pada perkembangan otak dan struktur anatominya. Dalam hal ini, manusia Plestosen di Indonesia telah memenuhi persyaratan itu. Dengan demikian dapat dianggap bahwa alat-alat batu Plestosen merupakan manifestasi dari faktor biologis penciptanya, yaitu manusia Plestosen itu sendiri. Di lain pihak, penerapan teknologi merupakan aspek yang paling nyata dari kebudayaan Plestosen. Atas dasar tersebut di atas, tampaklah bahwa teknologi Plestosen mencerminkan hasil adaptasi artara proses evolusi biologis terhadap kawasan penyesuaian dengan proses evolusi kebudayaan. Tingkat-tingkat 
teknologis menjelaskan perkembangan kebudayaan arkeologis. Kebudaya. an-kebudayaan arkeologis merupakan refleksi dari kondisi lingkungan dan cara manusia melakukan eksploitasinya.

\section{Kepustakaan:}

Howell, F. Clark. Manusia Purba (diterjemahkan dari "The Early 1977 Man” oleh dr. Th. S. Timan). Tira Pustaka, Jakarta.

Jacob, T. "'Evolusi Ekosystem Manusia", Berkala Ilmu Ke-

1977 dokteran Jilid IX nomor 1, Fakultas Kedokteran Universitas Gadjah Mada, Yogyakarta.

1978 "Prospek Penelitian Paleoanthropologi", Lokakarya Arkeologi 1978, Proyek Penelitian dan Penggalian Purbakala Jakarta.

Oakley, Kenneth P. Man the Tool-maker. University of Chicago Press. 1972

Soejono, R.P.

"'Penilaian Terhadap Perkembangan Paleolitik di 1980 Indonesia", Pertemuan Ilmiah Arkeologi I.

Pusat Penelitian Purbakala dan Peninggalan Nasional. 